\title{
Modification of Visual Characters in Indonesia Animation Film
}

\author{
Yully Ambarsih Ekawardhani ${ }^{\bowtie}$, Imam Santosa, \\ Hafiz Azis Ahmad, Irfansyah Irfansyah \\ Institut Teknologi Bandung, Indonesia
}

Submitted: December 18, 2019. Revised: July 9, 2020. Accepted: November 4, 2020

\begin{abstract}
This study aims to determine the relationship between facial physiognomy, body shape, and visualization of animated film character designs. Characterization in an animated film is inseparable from the characters who are placed to fulfill the film's role. In the creation of physiognomy and body shapes can be combined as an approach to design. The characters are modified through simplifications in the form of cartoons. This is done so that the visualization of the character gets closer to the role added, in addition to emphasizing the characteristics of one character to another. Even in animated films, characters become important elements to direct the understanding of stories. The approach used is interdisciplinary, given that in characters there is a merging of visual elements that need to be approached using different theories. The combination of theories used is personality theory through somatotype to find characters through body shapes, physiognomy from Ar-Razi and ming xiang to obtain character traits and the theory of simplifying shapes into cartoons. The result is a match between the characters played by the three reference elements. The interesting thing that was found was the application of different physiognomy between one character and another to reinforce the characteristics. So that in the film, these figures can represent roles, which are human presentations in real life.
\end{abstract}

Keywords: animation; character; physiognomy; somatotype personal test; visual modification

How to Cite: Ekawardhani, Y. A., Santosa, I., Ahmad, H. A., \& Irfansyah, I. (2020). Modification of Visual Characters in Indonesia Animation Film. Harmonia: Journal of Arts Research And Education, 20(2), 167-175

\section{INTRODUCTION}

The creation of characters in animated films is one of the important stages. The character plays a role so that it can influence the audience's imagination. The embodiment of animated film characters is inseparable from the modification of the form. The purpose of a modification is to simplify the characters so that their audience easily understands them. The concept of simplification refers to two aspects, first the technical aspects and the second aspects of the audience reception of the characters. The first reason refers to the technical making of animated film characters. When a character is made to move, it needs to be made thousands of images to make it seem moving. The second reason is that the simpler a character is, the easier it will be to remember. Observing this, it is necessary to look at research on characters that have been carried out, both in the context of the creation or design, and the examination of values in characters. Research on characters has been carried out, both

\footnotetext{
Corresponding author:

E-mail: yullyambarsih@student.itb.ac.id
} 
in the context of the creation or design, as well as the examination of values in characters. Fathoni, et al. (2018) research trace the application of physiognomy to be applied to character designs. Ahmad (2018) examines the physiology of Imam Shafi'i to explore one's character and behavior. Based on the exposure in these two studies, it can be explained that the elements of shape on a person's face can be known as the nature and tendency of the actions taken. Meanwhile, the creation of animated movie characters has its own complexities, especially when making moves. There are hundreds or even thousands of images to make them look like they are making certain moves. The process of drawing 'in-between' can be seen in Figure 1.

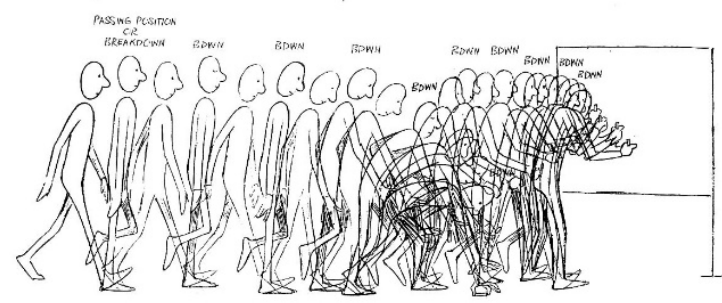

Figure 1. The process of "in between" in an animated film. (Taken from the book The Animator's Survival Kit)

Considering the complexity in designing characters, the simplification of forms is one aspect that impacts the consistency of the characters' likeness to humans as the comparison is a research on the animation industry in America. America has a long history of animated films, started by Walter Disney; the animation film industry in America continues to grow and develop. Disney brings animated film characters to have an affinity with the adult audience. The additional psychological character can create "emotional exchange" (Raffaelli, 2011). Animated films are understood as works of art produced in groups, so there is an elaboration of understanding of their existence in this case. According to Frank (2016), animated film, on the other hand, is made by a group of people in several stages, so that it can be said as "mosaic." As an artificial work, Einstein's theory of omnipotence through his character, which can be treated as plastic, has no gravity. Special treatments are used to make simplification of forms. The concept used in the creation of the film's character is a cartoon style, which is by making imperfect shapes compared to the human figure. However, this effort aims to make the characters easily recognizable through their forms.

Animated film characters also occupy certain positions, especially in the context of roles in the film. When created, there are considerations related to characterization, which in turn will have an impact on visualization. The discussion of the character is itself related to the characterization theory. According to Eder (2008) characters are central factors to gain understanding and experience, enjoy the aesthetics and rhetoric of films. It also contributes to the depth of emotions, thematics, and ideology. The character also becomes a reference for film criticism and analysis, as well as its position in the production process. Character models represent the properties of a fictional being in a particular structure, with particular transparency and a particular perspectival orientation. Eder (2010) also explains that characters are closely connected with other mental models that the viewers have formed of the situations of the story as well as of themselves or other persons.

This definition is further developed based on the delivery media; as explained on the dramatica.com site, the main character is "The player through whom the audience experiences the first hand story." It can be explained as "A character who moves the plot forward and serves as a surrogate for the audience." A character plays a role based on the existence of narratives that use dramaturgy. According to Madiana, et al. (2018), "The drama production was able to create a more creative local atmosphere with the involvement of drama in an organization or a drama production. The involvement of dramaturgy before, during, and after the drama is aired is a wise procedure to implement in a performance's process. The character's role 
becomes important because apart from being a story bearer, the character can position himself as someone's representative in the real world. In the film narrative of the Somat Family, there is a figure who is positioned as a leader, namely Somat. Somat is positioned as a father and husband who tries to protect his family. Refer to the article Junaidi (2017), who researched five leadership concepts in Javanese puppet plays. One of the things to be observed is the concept of Tripakarti, namely a king commits three actions so that his people do not underestimate him, namely: (1) among, which means caregiver, (2) Hamot, who is broad-minded, (3) and Hamemangkat, which means respecting the ability other people. In this context, a leader functions as a guide, educator, protector, unifier, and observer for his people. In the context of this animated film, Somat seeks to position himself as a leader who has an awareness of his shortcomings and always tries to do good with compassion.

In character creation, one of them is based on body shape. William Sheldon first put forward this theory in 1940. Genovese's (2008) explanation of Sheldon's typology is based on body shape or somatotype influenced by three components: endomorphy, mesomorphy, and ectomorphy. Endomorphy refers to the component of body fat. Mesomorphy emphasizes the muscles of the body, while ectomorphy refer to thin bodies. Sheldon also stated the link between somatotype and human behavior. Three fundamental dimensions of temperament can be associated with these physical components, namely (1) Visceratonia (associated with endomorphy) is characterized by weak, slow reactions to stimuli and likes eating activities and physical comfort, (2) Somatotonia (associated with mesomorphy) is characterized by assertiveness, risk-taking, aggressiveness, and indifference to pain and (3) Cerebrotonia (associated with ectomorphy) is characterized by physical and emotional restraints, rapid reactions to stimuli, and social inhibition (Sheldon, 1942).

In addition to the Somatotype Perso- nality Theory, there is also physiognomy, the science of reading a person's character through face shapes. This science is among the most ancient practical philosophies since Greek times by Aristotle. This knowledge has also developed among scholars of the Muslim community. One of those who was deeply involved was Imam Fakhruddin Ar-Razi (1150-1210), a famous scholar of his time. Ar-Razi wrote it in the hunch book. Foreboding is based on the arguments of the Koran, sunna, and logic (based on the book Ar-Razi which was reprinted in 2015. Furthermore, the quotations in this book refer to the print).

Two of the four verses in the Quran that explain it are QS. Al-Hijr: 75, states, "Verily in that are indeed signs (Our authority) for those who pay attention to signs (al-mutawassimûn)" and QS. Al-Fath: 29, states, "Their signs appear on their faces from the former prostration." The following basis is the argument based on reason: first, that humans are social beings who always interact with other humans, it is possible to meet various characters. Foreboding is essential to master to avoid encounters with humans whose personality does not suit him. Second, there are animal trainers who are able to know the character of an animal-based on their physical characteristics. If it can be applied to animals, it can be applied to humans. Third, physiognomy is based on natural science (al-'ilm ath-thabi'i), which has been tested through experimentation. If synchronized, physiognomy is in line with medical science.

Techniques to find out the character - a person's personality, namely: Based on the shape and appearance of a person; Based on the type of sound; Based on similarities with animals in certain physical forms; Based on the racial security features; Based on gender differences; Based on some characters that are already known.

Specifically, there are instructions from the body's organs, especially the much stronger head than other organs. The reason is that first, the virtue of being a human being is due to understanding 
and memory. Everything is stored in the brain, then the source of thought is in the head. This shows that the head is a member of the body "most perfect for showing psychological symptoms." Second, the perfection of the condition of the body is caused by "kebagusan" (al-husn), while the deficiency is referred to as "badness" (al-qubh). Both are dominantly located on the face. Third, the appearance that appears on the face is an inner moral guide. All expressions related to human feelings appear on the face. In detail, the instructions on the body's organs, especially the face, can be seen through the forehead, eyebrows, eyes, nose, lips, chin, and ears.

Besides being based on Ar-Razi physiognomy, the science of facial reading is also known in China, referred to as Ming Xing. The Chinese have been carried out more than 2000 years ago, until now it is still used to analyze intellectual abilities, personality traits, and the fate of a person. It is believed that a person's personality can be read clearly on his face (Lip, 1998). The character design refers to the form of a cartoon, in the form of simplification of the form compared to the reference, which is human. Firmly can be seen in the body shape that is not perfect and disproportionate. Although made in 3-dimensional form, but the figure's body shape has a cartoon characteristic. Cartoons themselves are described as funny images that are two-dimensional. The definition of cartoon develops over time and leads to a semirealistic form created as a satire, caricature, or humor.

These techniques are applied to characters in animated films as a case study is the animated film of the Keluarga Somat and Adit Sopo Jarwo. The two films use a different visual approach but look detailed in the cultivation of body and face shape. The figures that will be examined in this paper are Somat, Inah, and Jarwo. All three are figures which represent the body shape on the Somatotype Personality Theory. Somat and Inah represent the endomorphy and ectomorphy types, while Jarwo represents the mesomorphy type.

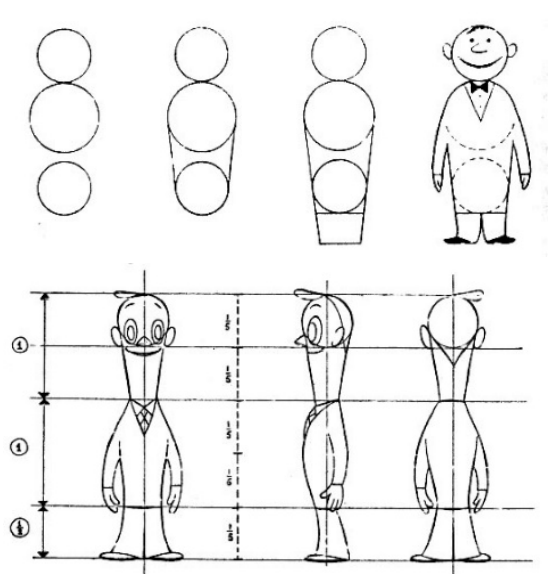

Figure 2. Proportion of humans in the form of cartoons (Halas \& Privet, 1958)

As explained before, regarding character based on body shape, this theory applies characters in animated films, facilitating these characters' interpretation. Combined with the theory of reading faces, completes the character placed in them. However, when the character is animated, the next issue is to adjust it to the interests of the animation. The Somatotype Personality Theory is a classical psychological theory, but it is still used because it shows visual features. It was simply adopted to divide the body shape, which is the triangles, circles, and rectangles. In the process of creation, narrative aspects are needed. It generally boils down to a good story that was executed well within the character design. Sometimes it deals with aesthetics, and we all know that aesthetics is dictated by the story of the character design (Tillman, 2011).

\section{METHOD}

Research on the visualization of characters in this film is carried out in the following stages: The first stage determines the character under study and examines the visual aspects of the captured parts. This determination is based on the different body shapes of these figures. The second stage describes the parts of the characters, including body shape and elements on the face. Each character has a different form of detail. The third stage is to link these ele- 
ments with each characterization. At this stage, an attempt is made to add properties based on physiognomy theory. The final stage is to link the results of the previous three stages with design visualization.

\section{RESULT AND DISCUSSION}

The elements on the face and body created through consideration of the Somatotype Personality Theory and physiognomy reinforce animated film characters' characterization. Both of these approaches are able to create quality characters that will be placed in the film, then perform the role.

Today, in computer graphics, several artists cherish the belief that the more realistic they can make their characters, the greater their worth. Animations that depict the realistic movement of hair or the presence of lifelike textures elicit reactions of awe. Artists are encouraged to rush headlong toward the goal of greater realism (Ratner, 2003). The application of believability to the main characters and supporters can be seen in the following discussion:

\section{Somat in the film Keluarga Somat}

\section{Based on the Somatotype Personality Theory.}

As seen in Figure 3, Somat body type is extreme endomorphy, characterized by a body that looks big because of a lot of fat; in the film, it is shown to eat delicious, but not excessive.

Somat is more shown as someone who has good friends, friendly, not uptight, and likes to help others. Despite having a position as head of the family and making him have the authority to govern his family members, Somat is more shown as a patient figure and protects his family. Somat needs Inah to solve the problem.

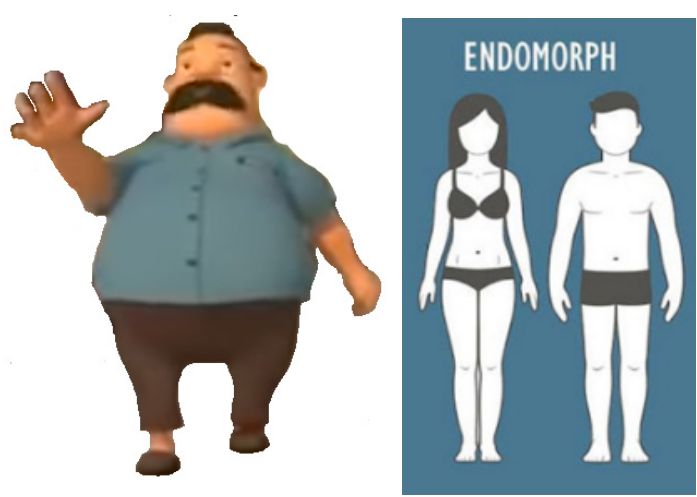

Figure 3. Somat is an extreme endomorph type

\section{Ar-Razi physiognomy and ming xiang}

Physiognomy is traced based on the face and the elements in the face, as follows:

Based on physiognomy, Somat is assertive, confident, wise, and easy to forgive. This description is in accordance with the role in the film as husband and father, who must protect his family. As seen in Table 1.

Table 1. Physiognomy of Somat

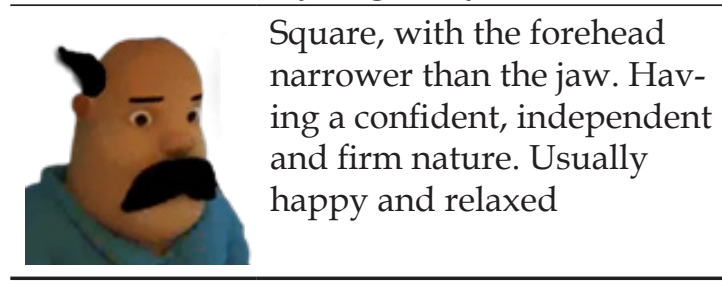

Slippery, wide and tall, tend to make quick decisions, practical, wise, kind and forgiving

Flat, straight eyebrows tend
to show ideas and like to
argue.
Big, naive.

Big, naive.
Bull nose type, has a peace-
ful nature and easy to feel
comfortable
$\begin{aligned} & \text { (covered with thick mus- } \\ & \text { tache) }\end{aligned}$


Based on physiognomy, Somat is assertive, confident, wise, and easy to forgive. This description is in accordance with the role in the film as husband and father, who must protect his family. As a father, Somat tries to provide comfort to his wife and children. This is in accordance with the shape of the face and nose. Meanwhile, when viewed from the forehead and eyebrows, Somat is able to make proportional decisions for his family.

\section{Visualization of character design}

Somat, has a very large body, then the shape of the head does not appear to exceed his body shape, but if you look at it as a whole has a rounded basic shape. To emphasize the nature and habits of Somat, it shown by the simplification of the form. Somat's basic body shape is round. The combination of the body and head of the Somat as a whole is oval in shape, with the body longer than the legs. Likewise, the soles of the feet are very small compared to the body and hands. This depiction gives a funny impression and confirms endomorphic characteristics, as shown in Figure 4.

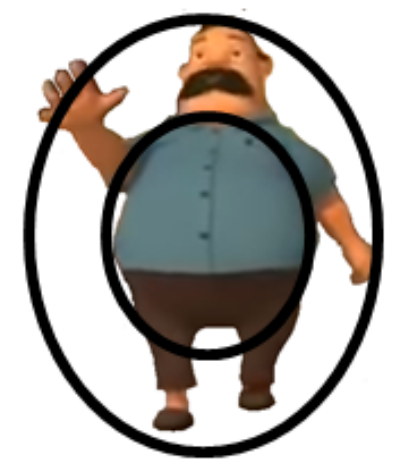

Figure 4. Somat body shape design

Inah

Based on the Somatotype Personality Theory

Inah's body type is small so that it can move quickly and carefully. Another trait of this body type is being calm and able to think fast (Figure 5).

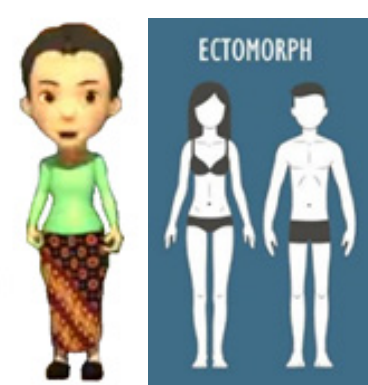

Figure 5. Inah is ectomorph type

This is adjusted to her position as a housewife, besides accompanying her husband also educating her children. Inah's ideal body shape, illustrates her pleasant nature. Despite her position as a wife and housewife, Inah also has a warung business to get additional family income. As a stall owner, Inah is always ready to serve buyers. This clarifies the shape of an agile ectomorphic body.

\section{Ar-Razi physiognomy dan ming xiang}

Inah's physiognomy can be seen in the Table 2.

Table 2. Physiognomy of Inah

\begin{tabular}{|c|c|}
\hline 0 & $\begin{array}{l}\text { Oval, with wide forehead } \\
\text { and narrow jaw. Having a } \\
\text { sense of taste and clever- } \\
\text { ness. }\end{array}$ \\
\hline & $\begin{array}{l}\text { Width and height, usually } \\
\text { smart, creative, practical } \\
\text { and like to forgive }\end{array}$ \\
\hline $1=$ & $\begin{array}{l}\text { Curving reflects intelligence } \\
\text { and compassion. }\end{array}$ \\
\hline 17 & $\begin{array}{l}\text { Big and far apart, naive and } \\
\text { kind }\end{array}$ \\
\hline & $\begin{array}{l}\text { Straight and balanced, have } \\
\text { a balanced intelligence and } \\
\text { personality }\end{array}$ \\
\hline & $\begin{array}{l}\text { Thin as the moon, has a } \\
\text { jovial nature }\end{array}$ \\
\hline
\end{tabular}

Inah's physiognomy shows kindness, intelligence, carefree, firm and practical. This trait supports his role as a housewife who must educate her children. 
Besides his position as a stall owner, must serve the buyer with a friendly but firm.

\section{Visualization of character design}

In contrast to Somat's endomorphy body, Inah has an ectomorphy type body. Although described as having an ideal body shape, Inah's visual approach is also an application of the cartoon style. She is seen from the comparison of body and head shape. Inah's head is made very large beyond the width of her body. Such depictions are not found in ordinary humans. This is done to reinforce the facial fisignomy, as shown in Figure 6.

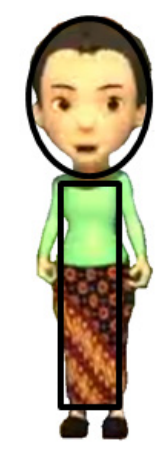

Figure 6. Comparison of the head and body of Inah

\section{Jarwo in the film Adit Sopo Jarwo}

\section{Based on the Somatotype Personality Theory.}

Jarwo's body type is mesomorphy, physically marked by a large shoulder section, shrinking to the abdomen. The traits that arise are related to the body's muscular shape so that it is oriented to physical activity (Figure 7).
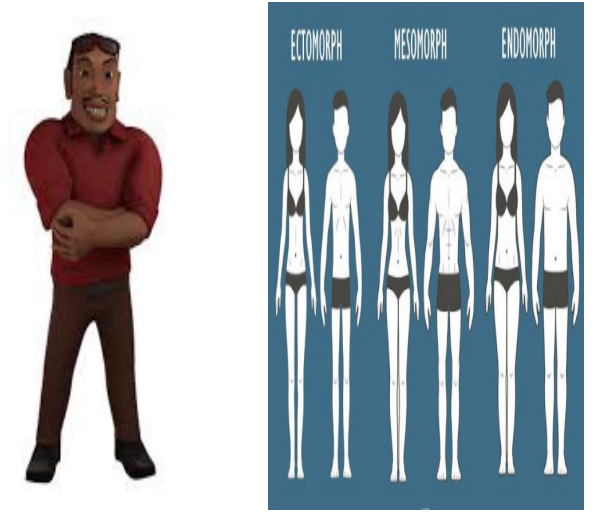

Figure 7. Jarwo is mesomorphy type
He has a loud voice and is straightforward. Jarwo is easy to express his thoughts, although the situation's interpretation is not always right. This happens because the temperament of somatotonic tends to be insensitive to the needs of others.

Another trait that is often shown in films is the figure who has many talents and often asks for help. However, Jarwo was realistic by asking for compensation for his services.

\section{Ar-Razi physiognomy dan ming xiang} Jarwo's physiognomy can be seen in the Table 3.

Table 3. Physiognomy of Jarwo

Square, individualistic
tendencies and have a
strong desire to achieve his
dreams. Will never be able
to be still and deft in mov-
ing. \begin{tabular}{l} 
Slippery, tend to make \\
quick decisions \\
$\begin{array}{l}\text { Flat, straight eyebrows tend } \\
\text { to show ideas and like to } \\
\text { argue. }\end{array}$ \\
$\begin{array}{l}\text { Protruding out, means talk- } \\
\text { ing a lot }\end{array}$ \\
$\begin{array}{l}\text { Snub, big nose, and snub, } \\
\text { usually will be owned by } \\
\text { those who are not rigid with } \\
\text { their surroundings, prag- } \\
\text { matic, only believe in them- } \\
\text { selves, easy to get along and } \\
\text { not afraid. }\end{array}$ \\
$\begin{array}{l}\text { Thick and square, usually } \\
\text { generous, have talent and } \\
\text { like to talk about what was } \\
\text { achieved }\end{array}$ \\
\hline
\end{tabular}

Based on physiognomy, Jarwo's character tends to be individualistic and quick to make decisions, and even tends to rush. Many ideas are in line with his penchant for boasting. Leaning toward kindness because they feel able to overcome all the problems of others. However, the arrogant nature tends to obstruct the kindness of his 
heart.

\section{Visualization of character design} Jarwo comes from the film Adit Sopo Jarwo, has a different type of character design. Jarwo's body shape is more proportional compared to Somat and Inah. However, the emphasis on body type is made strict and tends to be extreme. Traces of cartoon style can be seen in the unbalanced body and leg length comparison, as shown in Figure 8.

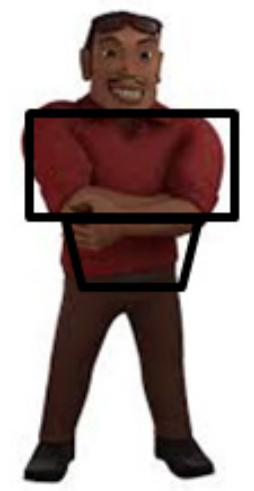

Figure 8. Jarwo body shape design

\section{CONCLUSIONS}

The complexity of animated film characters does not stop at being like a visual object but on its role in the film. Each character has different characteristics, in this case, supported by somatotype and physiognomy. The description of the nature is implemented through a character's design. Portrayal through cartoon style makes it easy to implement its characteristics. The cons of the body shape of Somat and Inah, who are husband and wife, make it easy to identify differences in nature between the two. Similarly, the depiction of Jarwo who has a large body, coupled with its dominant characteristics. Somatotype and physiognomy help create depictions of complexity in animated film characters. This makes these figures increasingly resemble humans with their nature and behavior.

\section{REFERENCES}

Ahmad, N. F. (2018). Fisiognomi Imam Sy- afii dalam Naskah Wirasat Sapii. Jurnal Nusa, 13 (2), 301-315

Ar-Razi, I. F. (2015). Kitab Firasat Ilmu Membaca Sifat dan Karakter Orang dari Bentuk Tubuhnya. Jakarta: Penerbit Turos Pustaka.

Eder, J. (2008). Film Characters: Theory, Analysis, Interpretation. Monograph. Marburg: Schüren

Eder, J. (2010). Understanding Characters. Berghahn Journals, 4(1), 16-40

Fathoni, A. F. C. A, Kartika R., Lubis, S. H. (2018). Penerapan Physiognomy Untuk Pengembangan Desain Karakter Pada Animasi. Jurnal Dimensi, 13(1), 31-42.

Frank, H. M. (2016). Looking at Cartoons: The Art, Labor, and Technology of American Cel Animation (Dissertation). Chicago: University of Chicago.

Genovese, J. E. C. (2008). Physique Correlates with Reproductive Success in an Archival Sample of Delinquent Youth. Evolutionary Psychology Journal, 6(3), 369-385.

Junaidi. (2017). Leadership Characters in Shadow Puppet Show. Harmonia: Journal of Arts Research and Education, 11(2), 181-189.

Lip, E. (1998). Seni Membaca Wajah. Malang: Kentindo Soho.

Madiana, B. I, Indrayuda, \& Effindi, B. S. M. (2018). The Application of Asa Berger Homour Technique by Sabri Yunus from The Dramaturgy Perception in "Karoot Komedi". Harmonia: Journal of Arts Research and Education, 18(2), 167-171.

O'Pray, M. (2011). Eisenstein and Stokes on Disney Film animation and omnipotence, 195-202 in Pilling, J., ed., Reader in Animation Studies. Lancaster: John Libbey Publishing Ltd.

Raffaelli, L. (2011). Disney, Warner Bros. and Japanese animation Three world views, 112-136 in Pilling, J., ed., Reader in Animation Studies. Lancaster: John Libbey Publishing Ltd.

Ratner, P. (2003). 3-D Human Modeling and Animation 2nd Edition. New Jersey: John Wiley \& Sons, Inc. 
Selby, A. (2009). Animation in Process. London: Laurence King Publishing.

Thomas, F. \& Johnston, O. (1984). The Illusion of Life Disney Animation. New York: Walt Disney Production.

Tillman, B. (2011). Creative Character Design. Waltham: Focal Press.

William, R. (2001). The Animator's Survival Kit. London-New York: Faber and Faber.

Yully, A. E., Imam S., \& Hafiz A. A. (2016). Konsep Believability pada Karak- ter Utama dalam Film Seri Animasi Adit dan Sopo Jarwo dan Keluarga Somat. Proceeding of the 2nd International Converence in Creative Media, Design and Technology (REKA 2016).

Yully A. E., Imam S., \& Hafiz A. A. (2016). Finding Identity and believability Character in Indonesia Animated Film. Proceeding of the $5^{\text {th }}$ International Seminar on Nusantara Heritage "From Nusantara Heritage toward South Eastasia Heritage." 